\title{
Derleme
}

Mersin Univ Saglık Bilim Derg 2021;14(1):133-145

doi:10.26559/mersinsbd.868398

\section{İzolasyon ve karantinanın ruh sağlı̆̆ı üzerine etkileri}

\author{
Eda Aslan1, (Deda Türkili1
}

${ }^{1}$ Mersin Üniversitesi Tıp Fakültesi, Psikiyatri AD

$\ddot{0} \mathbf{z}$

COVID-19 hastalı̆̆ına yol açan SARS-CoV-2 (şiddetli akut solunum yolu sendromu koronavirüsü 2) virüsü yaklaşı 1 ylldır tüm dünya gündeminin en önemli konusudur. Koronavirüs pandemisi fiziksel, ruhsal, sosyal, ekonomik ve daha birçok yönden yıkıcı etkilere sebep olmuştur ve bu yıkıcı etkileri devam etmektedir. Çok eski tarihlerden bu yana salgınlardan korunmak için kullanılan karantina ve izolasyon yöntemleri ise pandeminin başından bu yana hayatımızın ayrılmaz bir parçası olup hâlâ salgınlardan korunmanın en etkin yöntemlerinden birisidir. Salgınlarda etkisi kanitlanmış olan bu yöntem diğer yandan biyopsikososyal birçok olumsuz etkisini de beraberinde getirmektedir. Karantina dolayısıyla çalışamama ve kazancın azalması, aile içi şiddette artış, artmış çocuk ihmali/istismarı, alkol-madde kullanımında artış, damgalanma, sağlık çalışanları üzerindeki baskı ve iş yükünde artış, diğer fiziksel hastalıkların kontrolünün yapılamaması ve tedaviye ulaşamamaya bağlı kronik hastalıkların oluşturdukları sekeller, yaşlıların temel ihtiyaçlarını gidermelerindeki zorluklar ve sosyal geri çekilme kişilerde sıkıntı hissi, öfke, sinirlilik, kaygı gibi hayatın pek çok yönünü etkileyen önemli ruhsal etkilenime ve depresyon, anksiyete bozuklukları, travma sonrası stres bozukluğu gibi bir çok ruhsal bozukluğun ortaya çıkmasına sebep olmaktadır. Pandemi dönemlerinde ortaya çıkan ruhsal sorunların pandemi bittikten sonra da aylarca devam ettiği ve kişilerin işlevselliğini ve dolayısıyla toplumun işlevselliğini bozduğu geçmişte yapılan birçok çalışmada gösterilmiştir. Böylesine dramatik sonuçlara sebep olma riski taşıyan karantina ve izolasyonun başarılı bir şekilde yönetilmesi için yöneticilerin halka yönelik şeffaf bilgilendirme yapması, özel grupta yer alan kişilerin temel ihtiyaçlarının giderilmesi ve koruyucu ruh sağlığı hizmetlerinin güçlendirilmesi önem arz etmektedir.

Anahtar kelimeler: Pandemi, salgın, psikoloji, ruh sağlığı, ruhsal bozukluk

Sorumlu yazar: Eda Aslan, Mersin Üniversitesi Tıp Fakültesi Hastanesi, Psikiyatri AD, Çiftlikköy Kampüsü, Mersin, Tel: 0324 2410000-1764, E-posta: dredaaslan@yahoo.com 


\title{
The psychological impact of quarantine and isolation
}

\begin{abstract}
SARS-CoV-2 (Severe Acute Respiratory Syndrome Coronavirus-2) pandemic which causes COVID19 (Coronavirus disease 2019) has been the most important topic of the agenda all over the world for about 1 year. The pandemic has caused destructive effects in physical and mental health and also social, economic and many other aspects, and these destructive effects still continue. Quarantine and isolation methods, which have been used to protect against epidemics and pandemics since ancient times, have been an integral part of our lives since the beginning of the pandemic and are still one of the most effective methods of protection from epidemics and pandemics. This method, which has been proven to be effective, also brings many biopsychosocial negative effects along with it. Social withdrawal, being away from work and decrease in earnings, increase in domestic violence and child neglect / abuse, increase in alcohol-substance use, stigma, pressure and overload on healthcare workers, the sequelae of chronic diseases due to not having access to treatments, even difficulties in meeting basic needs due to quarantine cause significant psychological impacts such as distress, anger, irritability, anxiety, and many mental disorders such as depression, anxiety disorders, post-traumatic stress disorder during the pandemic. It has been shown in many past studies that the mental problems that occur during pandemic periods continue for months after the pandemic ends and disrupts the functionality of people and thus the functionality of the society. In order to successfully manage quarantine and isolation, which have the risk of causing such dramatic consequences, government officials should consider to provide transparent information to the public, to meet the basic needs of the people in the special group and to strengthen preventive mental health services.
\end{abstract}

Keywords: Pandemic, psychology, mental health, mental disorders

\section{Giriş}

I. İolasyon, karantina, sosyal mesafe tanımları ve insan ruh sağlı̆̆ı üzerine etkileri

Son bir yıldır dünya gündeminin merkezi haline gelen, şiddetli akut solunum yetmezliği isimli hastalığa (COVID-19) sebep olduğu için SARS-CoV-2 olarak adlandırılan koronavirüsün yol açtı̆̆ı pandemi küresel olarak fiziksel, ruhsal, sosyal, ekonomik ve daha birçok yönde yıkıcı etkilerini sürdürmektedir. Pandemik etkene yönelik bilinmezlikler, yüksek bulaşıcılık, hastalanma ve ölüm oranları ile kesin çözüm olabilecek tedavi olmaması sosyal mesafe, izolasyon ve karantina uygulamalarının salgınla mücadelenin odak noktası ve en etkili yolu olmasına neden olmuştur. Sosyal mesafe, izolasyon ve karantina uygulamaları geçmişten günümüze toplumların enfeksiyon hastalıklarından korunmasında uygulanan en etkili yöntemlerdir. M.Ö. 300400 'lü yıllarda Hipokrat'ın veba için en etkili korunma yolu olarak "derhal uzaklaşmayı" tavsiye ettiği bilinmektedir. 0 dönemde lepra, veba gibi hastalıklar için uygulanan bu yöntem, binlerce yıl sonra dahi salgınların önlenmesinde en etkili yöntemlerden biri olma özelliğini korumaktadır. Sosyal mesafe, izolasyon ve karantina benzer terimler şeklinde kullanılsa da aslında farklı tanımları kapsamaktadırlar. Sosyal mesafe, enfeksiyöz ajanın bulaşmasının önlenmesi için kişilerin kalabalık ortamlardan uzak durmak, zorunlu olmayan buluşmalara katılmamak, başkalarıyla aynı ortamda ise fiziksel mesafeyi korumak ve herhangi bir hastalık belirtisi hissettiğinde evde kalmak gibi uygulamaları içerir. İzolasyon ise, hasta insanların, sağlıklı bireylerden ayrı tutulması, faaliyetlerinin sinırlandırılması ile bulaşın önlenmesini ifade etmektedir. İzolasyon, sağlık kuruluşlarında sıkça uygulanan bir yöntemdir. İhtiyaca göre tek bir hasta odası izolasyona alınabildiği gibi herhangi bir klinik veya tüm hastane izolasyona alınabilir. İzolasyonda kişiye karşı temas bariyeri konulur ve kişinin 
yanına koruyucu ekipmanla yaklașılır. Geniș açıdan bakıldığında izolasyonun sadece fiziksel anlamda değil manevi anlamda da bir uzaklaşma olduğu görülmektedir. Özellikle sağlık personelinin fiziksel (koruyucu ekipman ve kapalı kapılarla fiziksel ayrılma) veya manevi (sevdiklerinden ayrılma, maskeli yüzlerden duygu okuyamama, dokunma temasının olmaması, koruyucu ekipmanlar içerisinde kişileri tanıyamama) izolasyonu, personelin meslektaşlarından sosyal destek almasını zorlaştırmakta, duygusal teması azaltmakta, personelin kendisini yalnız hissetmesine sebep olmakta ve yine aynı önlemler yüzünden hastanın da yalnız hissetmesine sebep olma riskini taşımaktadır. Karantina ise, bulaşıcı hastalık etkenine maruz kalan veya kaldığından şüphelenilen, hasta olma olasılığı olan ancak henüz hasta olmayan kişilerin, genellikle etkenin kuluçka süresi ile uyumlu şekilde geçici olarak tutulup gözlenmesi olarak uygulanan en eski korunma yöntemlerinden biridir. ${ }^{1}$

Güncel koronavirüs pandemisinde de toplumsal hareketliliğin bulaşın önlenmesi açısından gerek yurt içi gerekse uluslararası olarak kısıtlanması halk sağlının korunması açısından en öncelikli ve en önemli adım olarak ön plana çıkmıştır. Yirmibirinci yüzyılda bulaşıcı hastalıkların ortaya çıkma ve hızla yayılma riski nedeniyle karantina ve diğer halk sağlığı araçları halk sağlığının korunması bakımından merkezi bir rol oynamaktadır fakat bu stratejiler hemen her zaman çok tartışılan, kişisel haklara müdahale olarak görülen ve hangi siyasi rejim altında olursa olsun şüphe, güvensizlik ve zaman zaman isyanlara sebep olabilen durumlardır. ${ }^{2}$ Pandemi benzeri halk sağlığını etkileyen hastalıklarda kişilerden toplumun sağlığı için kendi haklarını aramaması beklenir ve bu durum oldukça hassas bir denge gerektirir. Günümüzde küresel iletişimin kolaylığı sebebiyle korku, panik, alarm hali tüm dünyada çok hızlı yayılmakta ve bu durum karantinanın olası olumsuz etkileri açısından riski arttırmaktadır. Karantina katı kuralları ile topluluğun çoğunu kapsadığı ve kişiler üzerinde baskı hissi uyandırdığı için bir takım psikolojik, sosyal ve hatta fiziksel problemleri de beraberinde getirmektedir. Karantina dolayısıyla çalışamama ve kazancın azalması, aile içi şiddette artış, artmış çocuk ihmali/istismarl, alkol-madde kullanımında artış, salgın mevcudiyetinde diğer fiziksel hastalıkların kontrolünün yapılmaması (azalan hastane başvuruları) ve tedaviye ulaşamamaya bağlı kronik hastalıkların oluşturdukları sekeller; sıkıntı hissi, öfke, sinirlilik, kaygı gibi hayatın pek çok yönünü etkileyen önemli sorunlar ortaya çıarabilmektedir. Şüphesiz ki insanların yararı için yapılması zorunlu olan bu uygulamaların olumlu etkilerinin yanında ortaya çıkan bu problemler salgın sırasında hafife alınabilmektedir. Dramatik sonuçları olması sebebiyle bu uygulamaların başarılı bir şekilde yönetilmesi önem arz etmektedir. Halk sağlığını korumayı amaçlayan bir yöntemin diğer yandan halkın sağlı̆̆ını bozması psikiyatrik sonuçları açısından üzerinde düşünülmesi gereken konulardır. Medya ve halk sağlı̆̆ genel olarak epidemilerin biyolojik ve fiziksel etkileri üzerinde durmakta, beraberinde ortaya çıkan psikiyatrik bazı durumlar arka plana atılmakta ve çevrenin tepkisinden dolayı psikiyatrik belirtiler gizlenebilmektedirler. Oysa salgınlar sona erdikten sonra psikiyatrik sekeller yaygın bir şekilde görülmekte ve uzun yillar devam edebilmektedir. ${ }^{3}$

Geçmişteki yapılan pandemi çalışmaları incelendiğinde karantina ve izolasyonun çeşitli psikiyatrik sorunlara sebep olduğunu görmekteyiz. SARS pandemisinde karantinanın psikolojik sonuçlarının araştırıldığı ve karantina altına alınan ve alınmayan kişilerin karşılaştırıldığı çalışmada sıkıntı hissi, depresyon, stres, keyifsizlik, irritabilite, öfke patlamaları, uykusuzluk, travma sonrası stres bozukluğu (TSSB) ve duygusal çökkünlük belirtilerinin karantinaya alınanlarda, karantinada olmayan kişilere göre çok daha fazla görüldügü bildirilmiştir. ${ }^{4}$ Karantina sonrasında kişiler \%7 oranında anksiyete, \%17 oranında yoğun öfke hissi belirtirken aynı kişilerere 4-6 ay sonra tekrar sorulduğunda \%3'ünde anksiyetenin ve $\% 6$ 'sında öfke patlamalarının devam ettiği bildirilmiştir. ${ }^{5}$ SARS sonrası yıllık izlemde karantinaya alınmış sağlık personellerinde alkol ve maddeye kötüye kullanımının 
olduğu ve bunun karantina ile başladı̆̆ gözlenmiștir. ${ }^{6}$ Karantina sonrası sağlık çalışanlarında kaçınma davranışı gözlenmiş, hastalarla temastan uzak durmaya çalıșma, ve çalışmaya isteksizlik bildirilmiştir. ${ }^{7}$ Yapılan bir çalışmada karantinaya alınan bölgelerdeki insanların \%54'ünün karantina sona erdikten sonra uzun süre öksüren ve hapışıran kişilerden uzak durmaya çalıştığı, \%26'sının kalabalığa giremediği, \%21'inin ise ortak alanlara giremediği ve kişilerin normal psikolojik durumlarına dönmelerinin aylar sürdüğü bildirilmiştir. ${ }^{3}$

Karantina sırasında sağlık çalışanlarında TSSB başta olmak üzere bir çok psikiyatrik belirtinin genel populasyona göre daha fazla görüldüğü bilinmektedir 8 . Sağlık çalışanlarının halihazırda enfekte olma korkusu, yakınlarını enfekte edeceği korkusu, bu korkuyla sevdiklerinden uzak durma ve suçluluk duygusu, içsel çatışmalar dışında sosyal çevreden görülen dışlayıcı tutumlar, etrafa enfeksiyon yaydıkları konusundaki suçlamalar bir çok ruh sağlığı problemini de beraberinde getirme riski taşımaktadır. Öfke, gerginlik hissi, mutsuzluk, çaresizlik hissi, tükenmişlik, sinirlilik, öfke patlamaları, suçluluk duygusunun karantinadaki sağlık çalışanlarında karantinadaki sağlık çalışanı olmayan kişilere göre daha sık görüldüğü bildirilmiştir. ${ }^{8}$

Günümüze geldiğimizde ise halihazırda yapılan çalışmalar değerlendirildiğinde bulguların benzer özellikler gösterdiği dikkat çekmektedir. COVID-19 pandemisinin başlarında Almanya'da sosyal mesafe, izolasyon ve karantina önlemlerinin ruhsal belirtiler ile ilişkisinin araştırıldığı bir çalışmada, daha yüksek kısıtlama seviyelerinin daha fazla yalnızlık, psikososyal sıkıntı ve daha düşük yaşam doyumu, daha yüksek anksiyete ve depresif semptomlar ile ilişkili olduğu saptanmıştır. $^{9}$ İtalya'da COVID-19 kısıtlamalarının genel popülasyonda ruh sağlığı etkilerinin araştırıldığı 18147 kişinin katıldığı bir çalışmada \%17.3 depresyon,
\%37 TSSB, \%20,8 anksiyete, \%7.3 uykusuzluk, \%21.8 algllanan yüksek stres ve \%22.9 uyum bozukluğu saptanmıştır. Bu çalışmada kadın cinsiyet ve genç yaşın tüm bozukluklar için risk faktörü olduğu saptanmış, karantinanın TSSB, anksiyete ve uyum bozukluğu ile ilişkili olduğu bulunmuştur. ${ }^{10}$ Yine COVID-19 pandemisinin başlarında Kanada'da yapılan bir çalışmada kısa vadeli sosyal uzaklaşma uygulamalarının bile panik, huzursuzluk, depresyon gibi psikolojik rahatsızlıklara neden olduğu saptanmıștır. ${ }^{11}$ Yine güncel pandemide İtalya'da uygulanan kısıtlamaların ruh sağlığına etkilerinin araştırıldığı bir diğer çalışmada da \%24.7 oranında depresyon, \%23.2 anksiyete ve \%42.2 uyku bozukluğu saptanmıştır. ${ }^{12}$ Yakın zamanda karantinanın psikolojik etkilerinin incelendiği bir derlemede, akut stres bozukluğu, TSSB, depresyon, sinirlilik, suçluluk duyguları ve uykusuzluğun karantina ile direkt ilişkili olduğu bildirilmiştir. ${ }^{4}$ (Tablo 1).

Karantinanın uzaması psikolojik etkilenmenin daha yoğun olması demektir. Bilimsel veriler ışığında karantinayı en makul sınırlarda tutmak insanların psikolojik olumsuz etkilenmeleri açısından önem taşıyor görünmektedir. Devam eden karantinanın uzatılacağının bildirilmesi uzatma ne kadar kısa olursa olsun kişilerde depresif duygudurumu arttırmaktadır. ${ }^{13}$ Karantina süresinin belirsizliği kişilerde tahammülsüzlük, gerginlik hislerine sebep olabilmekte ve süre uzadıkça kurallarda gevşeme olduğu gözlenmektedir. Zorunlu karantinalarda bu gevşeme halinin çok daha kısa süre içerisinde görüldüğü gözlenmekle birlikte gönüllü karantinada hem baskı hissinin azaldığı hem de gevşemenin daha az görüldüğü geçmiş çalışmalarda belirtilmiştir. ${ }^{14}$ Kișilerin gönüllü olarak evde kalması ve tedbir alması için anlaşılabilir ulaşllabilir bilginin onlara sürekli ve şeffaf bir şekilde ulaşması gerekmektedir. 
Tablo 1: İzolasyon ve Karantina Sürecinde Ortaya Çıkabilecek Belirti ve Bozukluklar

\begin{tabular}{|c|c|}
\hline $\begin{array}{l}\text { Ruhsal Belirtiler } \\
\text { - Sinirlilik, tahammülsüzlük } \\
\text { - Gerginlik hissi } \\
\text { - } \text { Mutsuzluk } \\
\text { - Ţaresizlik hissi } \\
\text { - Öfkenmişlik } \\
\text { - Suçluluk duygusu } \\
\text { - Yalnızlık } \\
\text { - Amaçsızlık } \\
\text { - Karamsarlık } \\
\text { - Uykusuzluk } \\
\text { - Beslenme alışkanlıklarında }\end{array}$ & $\begin{array}{l}\text { Ruhsal Bozukluklar } \\
\text { - Uyum Bozuklukları } \\
\text { - Anksiyete Bozuklukları } \\
\text { - Depresif Bozukluklar } \\
\text { - Akut Stres Tepkisi } \\
\text { - Uyku Bozuklukları } \\
\text { - Travma Sonrası Stres Bozukluğu } \\
\text { - Alkol-madde kullanım bozuklukları } \\
\text { - Mevcut ruhsal bozukluğun } \\
\text { kötüleşmesi }\end{array}$ \\
\hline
\end{tabular}

II. Karantina ve izolasyonun hassas gruplar üzerindeki ruhsal etkisi

Sosyal hayattan izole yaşamanın hâlihazırda birçok ruhsal hastalığı tetiklediği bilinmektedir. Etkilenmeler için mevcut derlememizde belirttiğimiz çeşitli risk faktörlerinin tanımlanması yanında ve COVID-19 karantina süresince belli gruplarda psikolojik etkilenmenin daha fazla olacağı endişesi mevcuttur (Tablo 2).

Tablo 2: İzolasyon ve karantina sürecinde ruhsal bozukluklar için risk faktörleri

- İleri Yaş

- Kadın cinsiyet

- Uzamış karantina süresi

- Sağlık çalışanı olmak

- Finansal belirsizlikler

- Temel ihtiyaçların karşılanmasında aksaklıklar

- Sosyal destek eksikliği

- Damgalanma hissi

- Geçmişten gelen psikiyatrik hastalık varlığı

\section{a. Yaşlı kişiler:}

Belli gruplara karantina uygulanması ayrımcllık, dışlanmışlık hissi, korkuda artış ve adaletsizlik duygusu oluşturabilmektedir. Örneğin ülkemizde de 20 yaş altı ve 65 yaş üstü kişilere uygulanan karantina kuralları bu grup dışındaki kişilerin bu gruplara karşı ayrımcı davranışlarına sebep olmuştur. ${ }^{15}$ Güncel COVID-19 pandemisinde ülkemizde 65 yaş üstü 556 katılımcı ile yapılan bir araştırmada, evde karantinaya alınan yaşlıların pandemiden psikolojik olarak etkilendiğini; bu grupta artan anksiyete düzeylerinin depresyon düzeylerini artırdığı saptanmıştır. ${ }^{16}$ Bir yandan enfeksiyöz ajan ile hastalanma olasılığı yüksek olan, diğer yandan kısıtlamalar nedeniyle günlük bakım ve temel ihtiyaçlarını karşılamakta zorlanan yaşlı popülasyonda depresyon ve anksiyete yaygın görülen psikiyatrik sorunlar olarak görünmektedir. ${ }^{17}$ Yapılan bir çalışmada COVID-19 pandemisi sırasında yaşlıların \%37.1'inin depresyon ve anksiyete yaşadığı bildirilmiştir. ${ }^{18}$ Bir diğer çalışmada ise, sosyal izolasyonun yaşlı bireylerde depresif 
bulguları ve anksiyete düzeyini arttırdığı ve depresyon semptomlarının yalnız hisseden ve sosyal destekten yoksun yaşlılarda daha yaygin olduğu gösterilmiştir. ${ }^{19}$ Hong Kong'da 2003 yılı SARS salginı sırasında yapılan bir araştırma, bu dönemde yaşlı bireyler arasında intihar oranlarının fazlalığını ve bu durumun muhtemelen yalnızlı ve iletişimsizlik sebebi ile olduğu bildirilmiştir. $^{20}$ Yaşlı hastaların medikal tedavilerine ulaşamaması, ihtiyaçları olan gıdaya dahi ulaşmakta sıkıntı çekmeleri, devam eden salgın kaygısı, ölüm korkusu, yalnızlık ve terkedilmişlik hissi çeşitli psikiyatrik hastalıklar için risk faktörleridir. Tıbbi hastalıklara bağlı morbidite ve mortalitenin izole olmayan kalabalık gruplarla yaşayan yaşlılarda daha az görüldügü bildirilmektedir. ${ }^{21} \mathrm{Bu}$ bağlamda, yaşlıları pandeminin fiziksel olumsuz etkilerinden korurken, diğer yandan gerek fiziksel gerekse ruhsal açıdan yakın takipleri, telefon ve diğer dijital ortamlarda temaslarının desteklenmesi, çevirimiçi sosyal destek, ruhsal destek ve teletıp uygulamaları ile yapılacak takip ve bilgilendirmeler bu grup için son derece önemlidir.22 Ülkemizde, sokağa çıma kısıtlaması olan 65 yaş ve üzeri vatandaşların alışveriş, temizlik ve sağlık kontrolü gibi ihtiyaçlarını karşılamak için yurt genelinde tüm il ve ilçelerde polis, jandarma, bekçi, AFAD personeli gibi gönüllü kamu çalışanlarından oluşan Vefa Sosyal Destek Grupları oluşturmuştur. ${ }^{23}$

\section{b. Coocuklar:}

Sosyal bağ kurmak, sosyal beceri öğrenmek çocuğun psikososyal yönü açısından gereklidir. Bir krize bağlı olarak ebeveynlerinden ve bakıcılarından ayrı kalan çocuklarda psikiyatrik hastalıklar daha sık görülmektedir. ${ }^{24}$ Yapılan bir çalışmada pandemiler sirasinda izolasyon veya karantinada bulunan çocuklarda akut stres bozukluğu, uyum bozukluğu ve komplike yas tepkisinin daha fazla görüldüğü bildirilmiştir; çocukların \%30'unda TSSB tanı kriterlerini karşılayan belirtiler olduğu bildirilmiştir. 25 Aileden ayrılma ve ebeveyn kaybının daha sonraki süreçlerde ruhsal hastalıklara yatkınlığı arttırdığı bilinmektedir; bu çocukların yetişkinlik döneminde duygudurum bozuklukları, psikotik bozukluklar ve intiharlar daha sık görülmektedir. ${ }^{26,27}$

\section{c. Sağlık personelleri:}

Karantinadaki sağlık çalışanlarında TSSB belirtilerinin karantinada olan diğer populasyona göre çok daha sık görüldügü bildirilmiştir. Buna ek olarak; damgalanma, kaçınma davranışları sağlık çalışanı olmayanlara göre daha fazla görülmektedir. Yapılan bir çalışmada sinirlilik, kolay öfkelenme, korku, bıkkınlık, gerginlik, yalnızlık hissi, üzüntü, endişe ve mutsuzluk gibi ruhsal belirtilerin diğer populasyonlara göre daha sık ortaya çıktığı, özellikle kadınlarda "enfeksiyon kapma ve etrafina bulaştırdıklarına dair kaygıların" daha fazla olduğu bildirilmiştir. ${ }^{28}$ SARS pandemisinde yapılan bir çalışmada, hastane çalışanlarında karantinaya alınma durumunun salgindan 3 yll sonra bile TSSB için bir belirleyici olduğu, alkol kötüye kullanımı veya bağımlılık belirtilerinin karantinaya alınan sağlık çalışanlarında daha fazla gözlendiği saptanmıştır. ${ }^{29}$ Hem en yüksek risk altında olan hem de hastalara müdahale eden grup olan sağlık çalışanlarına özellikle karantina ve sonrasinda psikososyal destek gerekmektedir. Ülkemizde dörtyüze yakın gönüllü psikiyatrist Türkiye Psikiyatri Derneği'nin sağlık çalışanlarına ruhsal destek hattı ile sağlık çalışanlarına özel psikososyal yardım hizmeti sunmuştur, amacına ulaştıktan sonra ise sonlandırılmıştır. ${ }^{30}$

\section{d. Önceden psikiyatrik tanısı olanlar:}

COVID-19 karantinasında psikiyatrik hastalarda TSSB, depresyon, anksiyete ve uykusuzluk, salgın hakkında kaygılanma, öfke, irritabilite ve intihar düşüncelerinin daha önce herhangi tanısı olmayan kişilere göre daha fazla görüldüğü yapılan çalışmalarda gösterilmiştir. ${ }^{31}$ Ağır ruhsal hastalığı olan 132 katılımcı ile yapılan bir araştırmada, 11 hastanın COVID-19 pandemisinden haberdar olmadığı, hastaların dörtte üçünün bulaş, hastalık semptomlarliyla ilgili yeterli bilgisinin olmadığl, üçte ikisinin pandemi önlemleri hakkında bilgisinin olmadığı, her 5 hastadan birinin bulaşma şekli hakkında bilgi sahibi olmadığı bildirilmiş olup hastaların 
\%30'unda karantina döneminde semptomların nüks ettiği bildirilmiştir. ${ }^{32}$ Yüksek nikotin tüketimi, eşlik eden tıbbi komorbiditeler, evsizlik, temel bakım ihtiyaçlarının karşılanmasındaki yetersizlikler bu grubu pandeminin gerek fiziksel gerekse ruhsal olumsuz etkilerine karşı savunmasız hale getirmektedir. Bulaş obsesyonları ve temizlik kompulsiyonları olan obsesif kompulsif bozukluk hastalarının da pandemi sürecinden olumsuz etkileneceği beklenmektedir.

\section{Karantina ve sonrasinda dikkat edilmesi gereken özel durumlar}

\section{a. Aile içi şiddet}

Karantinanın görünmeyen yüzü ise aile içi şiddet olaylarıdır. Aile içi şiddet ve istismar olgularının sosyal izolasyon ve karantina sürecinde arttığı bildirilmektedir; ekonomik stres, belirsizlik, öfkenin artışı ve tahammülün azalması, desteğin azalması olgu sayılarının artmasında başlıca sebepler olarak bildirilmiştir. ${ }^{33,34}$ Madde kötüye kullanımı, finansal zorluklar ve izolasyonun aile içi şiddet için risk faktörleri olduğu önceden beri bilinmektedir. ${ }^{35}$ Dışarıda içme alışkanlığı olan kişilerin evde alkol tüketimini arttırması, baş etme mekanizmaları kötü olanların alkole sığınması, izolasyon sırasında çalışamama, gelirde düşme aile içi şiddet açısından incelenmesi gereken risk faktörleridir. Özellikle çocukların okula gitmemesi, evden çıkamaması ile aile içi şiddete tanık olmaları artmış, ayrıca şiddetin ve ihmalin direkt kurbanları olmuşlardır. ${ }^{36}$ Çin'in Wuhan eyaltinde karantina sürecinde aile içi şiddetin 3 kat arttığı bildirilmiştir.37,38 Karantinanın bu yazı yazllırken henüz uygulandığı Amerika'da aile içi şiddet vakalarında \%21-\%35 artış görüldüğü bildirilmiştir. ${ }^{39}$ Çalışmalarda sağlıkla ilgili okul kapanmalarında çocukların daha kırılgan oldukları ve istismara daha çok uğradığı bildirilmiştir; karantinanın oluşturduğu ebeveyn stresinin çocuk istismarında etkisi önemlidir. ${ }^{40}$

\section{b. Tamamlanmamıs yas}

Yas bir kişinin kaybından sonra başlayan, bilişsel, duygusal, davranışsal ve sosyal değişimleri beraberinde getiren normal ve doğal bir tepkidir. Kaybı yaşayan kişinin kişilik özellikleri, olaylarla başa çlkabilme gücü, sosyal desteği ve kaybettiği kişiyle olan yakınlığı, kayıbı yaşadığı kişinin hayatındaki yeri ve anlamı yas sürecini etkileyen faktörlerdir. Tamamlanmış bir yas kişiyi iyileştirir ve yaşama daha kolay adapte olmasını sağlar. Yas kişisel faktörlerin yanında kültürel faktörlerle de ilişkilidir. Toplumumuzda ve birçok diğer toplumda ölümün arkasından dini ve kültürel ritüeller yapılır, belirli süreler içerisinde yakınlar toplanır, kayıp yaşanan kişi hakkında kişiler duygularını belirtir, yaslı kişiler desteklenir ve yas süreci bu șekilde kolaylaşır ve süresi kısalır. Oysa COVID- 19 pandemisi sırasında gördük ki kaybı yaşayan kişiler karantina uygulamalarından dolayı anne babası dahil en yakının cenazesini kaldıramadılar, kişiler yakınlarının yabancı kişiler tarafından herhangi ritüel olmadan cenazelerinin kaldırıldıklarını gördüler. Sosyal mesafe kuralından dolayı da yakınlarıyla birlikte olamadılar, yas sürecini paylaşamadılar. $\mathrm{Bu}$ durum tamamlanmamıș yas adı verilen depresyon başta olmak üzere çeşitli psikiyatrik sorunlara sebep olma riski taşımaktadır. ${ }^{41}$ Tamamlanmamış yas COVID19 sonrası üzerinde çalışılması gereken bir ruhsal halk sağlığı problemi olarak dikkati çekmektedir.

c. Intihar

Yalnızlık, izole yaşam ve sosyal desteğin COVID-19 izolasyon ve karantinası sırasında intiharların artacağ karantinanın ilk günlerinden bu yana mevcuttur, özellikle hassas grup olan psikiyatrik hastalar üzerinde intiharla sonuçlanacak dramatik etkilerin söz konusu olacağı en büyük endişeler arasındadır. Sadece kısa dönem değil uzun dönemde de bu etkilerin devam edeceği öngörülmekte ve bu da intiharı önleme programlarının üzerinde daha çok durulması gerektiğini göstermektedir. Yine intihar davranışının yordayıcılarından birisi olan aile içi şiddetin karantinada daha slk görüldüğü bilinmektedir; bu da intihar riskinin ne kadar yüksek olduğunu gözler önüne sermektedir. ${ }^{42}$ Son dönemlerde yapılan öngörme çalışmasında sadece finansal 
zorlukların bile intihar oranlarını 9 kat arttırması riskini tașıdığı bildirilmiștir. ${ }^{43}$ COVID-19 enfeksiyonu ile intihar düşünce ve davranışı arasındaki ilişkinin araştırıldığı bir çalışmada, 907 katılımcının \%17'sinin bir önceki ay intihar düşüncesinin olduğu ve yaklaşık \%5'inin bir önceki ay intihar girişiminde bulunduğu bildirilmiştir. ${ }^{44}$

\section{d. Damgalanma}

Salgınlarda sağlık personellerinin hastalıkları olmasa bile damgalanma yaşadıkları gösterilmiştir.45 Özellikle komşularının kendilerini istemediği, kaçındıkları, korku ve önyargıyla yaklaştıkları ve sürekli eleştirdiklerini belirten ve zaten pandeminin ağır yüzünü gören sağlık çalışanlarında sosyal destek yerine bu șekilde sosyal dişlanma TSSB, anksiyete bozukluğu ve majör depresif bozukluk gibi bozuklukların daha sık görülmesine sebep olmaktadır.45 Damgalanma sadece ev dışında olmamakta, ev içi aile üyeleri de sağlık çalışanının eve gelmesini risk olarak görmekte, kişiden olabildiğince uzak durmaya çalışmakta, eve gelmelerini istememektedirler. Bu yüzden başka yerde konaklama çabasına giren sağlık çalışanları damgalanmaya ve dışlanma sebebiyle ruhsal bozukluklara daha yatkın hale gelmektedir. Damgalanma endişesi kişinin içe kapanmasına, hastalık hakkında suskun kalmasına, hastalık belirtilerini saklamasına ve ortaya çlkan ruhsal belirti dahil herhangi bir belirtide sağlı yardımı arayışına girmemesine sebep olmaktadır. ${ }^{46}$ Yöneticilerin salgın hakkında ayrıntılı ve güncel bilgileri aktarmaları, karantinanın sebeplerini açıklamaları, karantinanın ne kadar süreceği hakkında yaklaşık bilgi vermeleri belirsizliğin azalmasına dolayısıyla da damgalanmanın daha az görülmesine sebep olacaktır. Medyadaki dramatik başlıklar ve korkuyu arttıran haberler damgalanmayı arttırabilir. 0 yüzden sağlık bakanlığının açık, net, hızlı bilgiyi an ve an medya (özellikle televizyon, radyo) üzerinden yayınlanması ve halkın durumu anlamasını sağlaması damgalanmanın önüne geçebilecek en önemli adımlardan birisidir.

\section{e. Finansal belirsizlik ve ișsizlik}

Sosyal izolasyon ve karantina uygulamaları toplumun pek çok kesimi için ekonomik zorlukları beraberinde getirmiştir. Yapılan çalışmalarda karantina sonucu gelișen ekonomik kayıpların ciddi düzeyde sosyoekonomik sıkıntılar yarattığı ve bunun da ruhsal bozukluk belirtileri için risk faktörü olduğu gösterilmiştir. ${ }^{4}$ Karantina ile birlikte ortaya çıkan dışarı çıkamama, işe gidememe, alternatif çözüm yolları planlamadan profesyonel işlerin ani şekilde sekteye uğraması karantina sırasında ve sonrasinda finansal zorlanmalara sebep olmaktadır. Karantinaya bağlı finansal zorlanmalar sonrası ortaya çıkan psikiyatrik belirtilerin (depresyon, anksiyete, panik ataklar) aylar ve hatta yıllarca sürdüğü bilinmektedir. 47 Özellikle sosyal etkileşim gerektiren işlerde oluşan bağlantı kayıpları finansal zorlanmaların daha da uzun sürdügünü göstermektedir. Karantina altındaki kişilere finansal yardımda bulunulsa bile kişilerin yine de verilen miktarın yetersiz olduğunu ve ayrıca dışarıya bağımlı olmanın yetersizlik ve çaresizlik hissini de birlikte getirdiğini ifade etmişlerdir; bu kişilerde depresif belirtilerin daha yoğun olduğu bildirilmiştir. 48 20002011 yılları arasında, 63 ülkenin verilerinin dahil edildiği bir araştırmada, intihar oranlarının ișsizlikle \%20-30 oranında arttığı gösterilmiştir. ${ }^{49}$ Bangladeş'te COVID19 nedenli 8 intihar vakasının değerlendirildiği araştırmada, vakaların 7'sinin ekonomik sorunlarla ilişkili olduğu; yine Pakistan'da COVID-19 sürecinde intihar eden 19 vakanın hepsinde ekonomik sıkıntıların olduğu gösterilmiştir. ${ }^{50}$

Karantinadaki kişilerin bu gelir açıklarının devlet tarafından belirlenmesi ve karşılanması gerekmektedir, fakat bu karantina veya herhangi bir afet/felaket öncesi planlanmış belirlenmiş koşullarda yapılandırılmalı ve direkt faaliyete geçirilmelidir. Karantinanın ilan edildiğinde yapılandırılmış herhangi plan yoksa bir an önce bu konuda komisyon kurulması gerekmektedir. Eğer evden çalışma mümkünse çalışanların evden çalışması özendirilebilir fakat unutulmaması gereken durum kişiler ev koşullarında genel olarak performanslarinın altında çalışabilmektedirler, o yüzden beklentilerin bu doğrultuda olması gerekmektedir. Mevcut 
ev koşulları, karantinanın verdiği bıkkınlık hissi verimlilikte azalmaya neden olmakla birlikte çalışıyor olma fikri kişilerin kendilerini yeterli hissetmelerine ve bıkkınlık hislerinin azalmalarına sebep olabilmektedir. İş arkadaşlarının birbirlerine sosyal destek vermeleri ve sürekli iletişim halinde olmaları kişilerin psikolojik zorlanmalarının azalmasına ve üretkenliğin artmasina sebep olacaktır.

\section{Karantinanın olumsuz etkilerini azaltmak}

Karantina bir stres faktörüdür, daha uzun karantina daha uzun stres anlamına gelmektedir. Karantina süresini aşırı ihtiyatlı davranmayarak bilimsel çerçevede inkubasyon süresine göre belirlemek gerekmektedir. Ayrıca uzmanların söylediği süre kadar karantina olması ve uzatılmaması önemlidir, değiştirilen karantina süreleri insanlarda belirsizlik hissinin artmasına ve halkta güvensizlik oluşmasına sebep olabilmektedir. Karantinanın uzamasının ne kadar kısa süreli olursa olsun çöküntü ve keyifsizliği arttıracağı akılda tutulmalıdır. Karantinadaki kişiler bedensel belirtilerini salgına yormaya eğilimlidirler, belirtiler felaketleştirilir ve bu durum her ne kadar salgın dönemlerinde çoğu kişide görülse de özellikle bilgilendirmenin yetersiz olduğu kişilerde "riskin boyutu", "neden karantina altında olduklarının" bilinmemesi korkularda artışa neden olmaktadır. Karantina altında olan kişilerin karantinanın sebepleri, hastalığın yayılımı ve gidişatı hakkında yeterli bilgilendirilmesi en öncelikli durumdur.

İnsanların temel ihtiyaçlarını karșlayabilmeleri hayati öneme sahiptir. Bu ihtiyaçların tedariki ve ihtiyaç duyanlara ulaştırılmaları için koordinasyonun sağlanması gerekmektedir. İhtiyaçların belirlenmesi ve ihtiyaç sahiplerine verilebilmesi, kaynakların tükenmemesi için oluşturulacak olan planlar son derece önemlidir. Karantinaya alınan kişilerde sıkıntı ve bıkkınlık hissini azaltmak için baş etme yolları öğretilmelidir. Çeşitli iletişim cihazları ile sosyal iletişimi arttırmak uzun dönemde ortaya çıkma ihtimali olan ruhsal hastalık riskini azaltmaktadır, sosyal medyanın kişilerin uzaktaki ailelerine ulaşmak, onlara iyi olduğunu bildirmek adına olumlu etkileri olabilir. Karantina altındaki kișilerin telefon kullanımlarına destek olmak (özellikle hastane içi), aileleri ve sevdikleriyle iletişim kurmalarını sağlamak izolasyon hissi, stres ve paniği azaltacaktır. Semptomlar ortaya çıktığında hangi sağlık kuruluşlarının telefonlarına ulaşmaları gerektiği de karantinada olan kişilere bildirilmeli, hastalığın ortaya çıkması halinde onlara sağlık hizmeti verileceğinin güvencesi verilmelidir. Karantinada, izolasyonda, tecritte olan kişilere hatırlandıkları, unutulmadıkları ve sağlık personelinin ihtiyaç halinde hemen yanında olacaklarının güvencesinin verilmesi korku, endişe, kaygı, öfke gibi duyguların azalmasını sağlayacaktır (Tablo 3).

Tablo 3: İzolasyon ve karantina sürecinde ruhsal etkilenmenin azaltılması için öneriler
- Halk sağlığı ile bireysel özgürlükler arasındaki hassas dengenin sağlanması
- Düzenli, şeffaf ve kapsamlı iletişimin sağlanması
- Temel ihtiyaçların sağlanmasının desteklenmesi
- Finansal destek
· $\quad$ Aile içi şiddetin önlenmesine yönelik müdahalelerin uygulanması
- Kesintiye uğrayan eğitim ve öğretimin telafisi
- Toplumdaki kırılgan grupları takibi
- Ruhsal müdahalelerin hayata geçirilmesi 


\section{Sonuç}

Sonuç olarak izolasyon ve karantina, salgın dönemlerinde yaşamsal öneme sahiptir ve gerektiğinde mutlaka uygulanmalıdır fakat uygulanırken halk sağlığı ile bireysel özgürlükler arasındaki hassas denge sağlanmalıdır. Halkı hastalıktan korumaya çalışırken bir diğer yandan karantinanın sebep olduğu birçok stresör ile ağır psikojenik zararlara maruz bırakmamak gerekir. Risk yönetimi ve halk sağlığının dengeli bir şekilde korunması önem arz etmektedir. Karantina uygulanması ruh sağlığı açısından önerilmese de pandeminin olağan etkilerinin insanların psikolojisini çok daha kötü etkileme riski vardır. Halk sağlığını korumak adına bazı grupları kısıtlamak oldukça tartışmalı ve dikkatle ele alınması gereken bir konudur. Karantina kaçınılmaz ise yetkililer bunu insanlar için başa çıkılabilir șekilde uygulamalıdırlar. Düzenli, șeffaf ve kapsamlı bir iletişim halkın güvenini kazanmaya yol açar, böylelikle de toplumların karantina kurallarına bağlılık ve uyum göstermesi ile halk sağlı̆̆ının korunmasında bașarı elde edilir. Süreç içerisinde kişilerin aktivitelerine nasıl yardımcı olunabileceği; su, yemek, ilaç gibi en temel ihtiyaçların sağlanmasında uygulanacak destekler ile ilgili bilgilendirme, durgunlaşan ekonomi ve finansal kayıplar konusunda halkın desteklenmesi, kesintiye uğrayan eğitim ve öğretimin telafisinin sağlanması kișilerin kısıtlamalara uyumunu kolaylaştıracaktır. Tüm bunları yaparken diğer yandan da toplumdaki kırılgan grupların belirlenmesi, temel gereksinimler noktasında desteklenmeleri ve başta hassas gruplar olmak üzere toplumun tüm kesimlerine koruyucu ve tedavi edici ruh sağlığı hizmetlerinin ulaştırılması pandemi ve sonrası dönemde son derece önemlidir.

Yazar katkısı: Tüm yazarlar makalenin planlanması, yazılması, revize edilmesi ve son halinin kabul edilmesinde katkıda bulunmuştur.

Çıkar çatışması: Yazarlar arasında herhangi bir çlkar çatışması bulunmamaktadır.
Mali destek: $\mathrm{Bu}$ çalıșma sırasında kamu, ticari veya kar amacı gütmeyen sektörlerdeki fon ajanslarından herhangi bir destek alınmamıştır.

\section{Kaynaklar}

1. T.C. Sağlık Bakanlığı Covıd-19 Bilgilendirme Sayfası. Erişim yeri: https://covid19.saglik.gov.tr/TR66507/s.html. 22.01.2021 tarihinde erişilmiştir.

2. Renaud K, van Schaik P, Irons A, Wilford S. 2020 UK Lockdown Cyber Narratives: the Secure, the Insecure and the Worrying. 11 June 2020. Access by: https://arxiv.org/abs/2006.06340. Access Date: 1 June 2021

3. Brooks SK, Webster RK, Smith LE, et al. The psychological impact of quarantine and how to reduce it: rapid review of the evidence.

Lancet 2020;395(10227):912-920. doi:10.1016/S0140-6736(20)30460-8

4. Jeong H, Yim HW, Song YJ, et al. Mental health status of people isolated due to Middle East Respiratory Syndrome. Epidemiol Health. 2016;38: e2016048. doi:10.4178/epih.e2016048

5. Caleo G, Duncombe J, Jephcott F, et al. The factors affecting household transmission dynamics and community compliance with Ebola control measures: A mixed-methods study in a rural village in Sierra Leone. BMC Public Health. 2018; 18: 1-13. doi:10.1186/s12889-018-5158-6

6. Bai YM, Lin CC, Lin CY, Chen JY, Chue CM, Chou P. Survey of stress reactions among health care workers involved with the SARS outbreak. Psychiatr Serv. 2004; 55(9): 1055-1057. doi:10.1176/appi.ps.55.9.1055

7. Braunack-Mayer A, Tooher R, Collins JE, Street JM, Marshall H. Understanding the school community's response to school closures during the H1N1 2009 influenza pandemic. BMC Public Health. 2013;13(1):1-5. doi:10.1186/14712458-13-344 
8. Reynolds DL, Garay JR, Deamond SL, Moran MK, Gold W, Styra R. Understanding, compliance and psychological impact of the SARS quarantine experience. Epidemiol Infect. 2008;136 (7): 997-1007. doi:10.1017/S0950268807009156

9. Benke C, Autenrieth LK, Asselmann E, Pané-Farré CA. Lockdown, quarantine measures, and social distancing: Associations with depression, anxiety and distress at the beginning of the COVID-19 pandemic among adults from Germany. Psychiatry Res. 2020;293: 113462.

doi:10.1016/j.psychres.2020.113462

10. Rossi R, Socci V, Talevi D, et al. COVID-19 Pandemic and Lockdown Measures Impact on Mental Health Among the General Population in Italy. Front Psychiatry. $\quad 2020 ; 11: \quad 790$. doi:10.3389/fpsyt.2020.00790

11. Best LA, Law MA, Roach S, Wilbiks JMP. The Psychological Impact of COVID-19 in Canada: Effects of Social Isolation During the Initial Response. Can Psychol. $2020 \quad$ Page unidentified. doi:10.1037/cap0000254

12. Gualano MR, Lo Moro G, Voglino G, Bert F, Siliquini R. Effects of COVID-19 lockdown on mental health and sleep disturbances in Italy. Int J Environ Res Public Health. 2020: 17(13): 4779. doi:10.3390/ijerph17134779

13. 12. Brooks SK, Webster RK, Smith LE, et al. The psychological impact of quarantine and how to reduce it: rapid review of the evidence. Lancet. 2020;395(10227):912-920. doi:10.1016/S0140-6736(20)30460-8

14. Rona RJ, Fear NT, Hull L, et al. Mental health consequences of overstretch in the UK armed forces: First phase of a cohort study. Br Med J. 2007; 335(7620): 603.

doi:10.1136/bmj.39274.585752.BE

15. Xin $M$, Luo $S$, She $R$, et al. Negative cognitive and psychological correlates of mandatory quarantine during the initial COVID-19 outbreak in China. Am
Psychol. 2020;75(5):607-617. doi:10.1037/amp0000692

16. Altın Z. Covid-19 Pandemisinde Yaşlılar. Tepecik Eğit ve Araşt Hast Derg. 2020;30:49-57. doi:10.5222/terh.2020.93723

17. Yıldırım H, Işık K AR. No TitleThe effect of anxiety levels of elderly people in quarantine on depression during covid19 pandemic. Social Work in Public Health 2021; 36(2):194-204. doi:10.1080/19371918.2020.1868372

18. Yang $Y$, Li W, Zhang Q, Zhang L, Cheung T, Xiang YT. Mental health services for older adults in China during the COVID19 outbreak. The Lancet Psychiatry. The Lancet Psychiatry, 2020; 7(4): 19. doi:10.1016/S2215-0366(20)30079-1

19. Meng H, Xu Y, Dai J, Zhang Y, Liu B, Yang $\mathrm{H}$. The Psychological effect of COVID-19 on the Elderly in China. Psychiatry Res. 2020;289:112983. doi: 10.1016/j.psychres.2020.112983

20. Santini ZI, Jose PE, York Cornwell E, et al. Social disconnectedness, perceived isolation, and symptoms of depression and anxiety among older Americans (NSHAP): a longitudinal mediation analysis. Lancet Public Heal. 2020;5:6270. doi:10.1016/S24682667(19)30230-0

21. Vefa Sosyal Destek Grupları, 65 Yaș ve Üstü ile Kronik Rahatsızlığı Olanlara Sokağa Çıkma Yasağı Genelgesi. Erişim Yeri: https://www.icisleri.gov.tr/65yas-ve-ustu-ile-kronik-rahatsizligiolanlara-sokaga-cikma-yasagi-genelgesi Erişim tarihi: 23.02.2021

22. Norredam M, Nellums L, Nielsen RS, Byberg $\mathrm{S}$, Petersen $\mathrm{JH}$. Incidence of psychiatric disorders among accompanied and unaccompanied asylum-seeking children in Denmark: a nation-wide register-based cohort study. Eur Child Adolesc Psychiatry. 2018: $\quad$ 7(4):439-446. doi:10.1007/s00787-018-1122-3

23. Sprang G, Silman M. Posttraumatic stress disorder in parents and youth after health-related disasters. Disaster 
Med Public Health Prep. 2013; 7(1):10510. doi:10.1017/dmp.2013.22

24. Santavirta T, Santavirta N, Betancourt TS, Gilman SE. Long term mental health outcomes of Finnish children evacuated to Swedish families during the second world war and their non-evacuated siblings: Cohort study. BMJ. 2015;15 (350):7753. doi:10.1136/bmj.g7753

25. Abel KM, Heuvelman HP, Jörgensen L, et al. Severe bereavement stress during the prenatal and childhood periods and risk of psychosis in later life: Population based cohort study. BMJ. 2014;348:7679. doi:10.1136/bmj.f7679

26. Taylor MR, Agho KE, Stevens GJ, Raphael B. Factors influencing psychological distress during a disease epidemic: Data from Australia's first outbreak of equine influenza. BMC Public Health. 2008 8:347. doi:10.1186/1471-2458-8-347

27. Wu P, Liu X, Fang Y, et al. Alcohol abuse/dependence symptoms among hospital employees exposed to a SARS outbreak. Alcohol Alcohol. 2008;43(6): 706-712. doi:10.1093/alcalc/agn073

28. Türkiye Psikiyatri Derneği Sağlık Çalışanları Ruhsal Destek Hattı. https://www.psikiyatri.org.tr/2207/tu rkiye-psikiyatri-dernegi-saglikcalisanlari-ruhsal-destek-hatti. Erişim Tarihi: 21.01.2021

29. Hao F, Tan W, Jiang $L$, et al. Do psychiatric patients experience more psychiatric symptoms during COVID-19 pandemic and lockdown? A case-control study with service and research implications for immunopsychiatry. Brain Behav Immun. 2020;87:100-106. doi:10.1016/j.bbi.2020.04.069

30. Muruganandam $P$, Neelamegam $S$, Menon V, Alexander J, Chaturvedi SK. COVID-19 and Severe Mental Illness: Impact on patients and its relation with their awareness about COVID-19. Psychiatry Res. 2020;291:113265. doi:10.1016/j.psychres.2020.113265

31. Moffitt P, Aujla W, Giesbrecht CJ, Grant I, Straatman AL. Intimate Partner Violence and COVID-19 in Rural, Remote, and
Northern Canada: Relationship, Vulnerability and Risk. J Fam Violence. 2020: 35(6): 1-12. doi:10.1007/s10896020-00212-X

32. Pandemics and Violence Against Women and Children | Center For Global Development. Erişim Yeri: https://www.cgdev.org/publication/pa ndemics-and-violence-against-womenand-children. Access date: 21 Ocak 2021.

33. Richards TN, Tillyer MS, Wright EM. Intimate partner violence and the overlap of perpetration and victimization: Considering the influence of physical, sexual, and emotional abuse in childhood. Child Abus Negl. 2017: 67:240-248.

doi:10.1016/j.chiabu.2017.02.037

34. Duncan TK, Weaver JL, Zakrison TL, et al. Domestic Violence and Safe Storage of Firearms in the COVID-19 Era. Ann Surg. 2020;272(2):e55-e57. doi:10.1097/SLA.0000000000004088

35. Lakhan R, Agrawal A, Sharma M. Prevalence of Depression, Anxiety, and Stress during COVID-19 Pandemic. J Neurosci Rural Pract. 2020;11(4):519525. doi:10.1055/s-0040-1716442

36. Organization WH. COVID-19 and Violence against Women What the Health Sector/System Can Do. Erişim Yeri:

https://www.womensaid.org.uk/theimpact-of-covid-19-on-women-andchildren-experiencing-domestic-abuseand-the-. Access date: 21 Ocak 2021.

37. Wagers S, Radatz DL. Emerging Treatment Models and Programs in Intimate Partner Violence Treatment: An Introduction. Partner Abuse. 2020: 11(3): 202-227. doi:10.1891/PA-20200015

38. Plan-International.Org/Ebolareport Young Lives on Lockdown: The Impact of Ebola on Children and Communities in Liberia Interim Report Erişim Yeri: https://resourcecentre.savethechildren .net/node/8708/pdf/liberialockdownexecutivesummary_0.pdf Access date: 
21 Ocak 2021.

39. Kübler-Ross, E., \& Kessler, D. On grief and grieving: Finding the meaning of grief through the five stages of loss. New York, NY: Scribner. 2005

40. Monteith LL, Holliday R, Brown TL, Brenner LA, Mohatt N V. Preventing Suicide in Rural Communities During the COVID-19 Pandemic. J Rural Heal. 2021: In press. doi:10.1111/jrh.12448

41. Kawohl W, Nordt C. COVID-19, unemployment, and suicide. The Lancet Psychiatry. 2020; 7 (5): 389-390. doi:10.1016/S2215-0366(20)30141-3

42. Ammerman BA, Burke TA, Jacobucci R, McClure K. Preliminary investigation of the association between COVID-19 and suicidal thoughts and behaviors in the U.S. J Psychiatr Res. 2021:15;134:32-38. doi:10.1016/j.jpsychires.2020.12.037

43. Huang JZ, Han MF, Luo TD, Ren AK, Zhou XP. Mental health survey of medical staff in a tertiary infectious disease hospital for COVID-19. Zhonghua Lao Dong Wei Sheng Zhi Ye Bing Za Zhi. 2020: 20;38(3):192-195.

doi:10.3760/cma.j.cn12109420200219-00063

44. Corrigan PW, Druss BG, Perlick DA. The impact of mental illness stigma on seeking and participating in mental health care. Psychol Sci Public Interes Suppl. 2014: 15(2):37-70. doi:10.1177/1529100614531398

45. Wilson JM, Lee J, Fitzgerald HN, Oosterhoff B, Sevi B, Shook NJ. Job Insecurity and Financial Concern During the COVID-19 Pandemic Are Associated With Worse Mental Health. J Occup Environ Med. 2020;62(9):686-691. doi:10.1097/JOM.0000000000001962

46. Desclaux A, Badji D, Ndione AG, Sow K. Accepted monitoring or endured quarantine? Ebola contacts' perceptions in Senegal. Soc Sci Med. 2017:78:38-45. doi:10.1016/j.socscimed.2017.02.009

47. Nordt C, Warnke I, Seifritz E, Kawohl W. Modelling suicide and unemployment: A longitudinal analysis covering 63 countries, 2000-11. The Lancet Psychiatry. 2015:2(3):239-45. doi:10.1016/S2215-0366(14)00118-7

48. Bhuiyan AKMI, Sakib N, Pakpour AH, Griffiths MD, Mamun MA. COVID-19Related Suicides in Bangladesh Due to Lockdown and Economic Factors: Case Study Evidence from Media Reports. Int $J$ Ment Health Addict. 2020: 15 :1-6. doi:10.1007/s11469-020-00307-y

49. Desclaux A, Badji D, Ndione AG, Sow K. Accepted monitoring or endured quarantine? Ebola contacts' perceptions in Senegal. Soc Sci Med. 2017:78:38-45. doi:10.1016/j.socscimed.2017.02.009

50. Nordt C, Warnke I, Seifritz E, Kawohl W. Modelling suicide and unemployment: A longitudinal analysis covering 63 countries, 2000-11. The Lancet Psychiatry. 2015:2(3):239-45. doi:10.1016/S2215-0366(14)00118-7

51. Bhuiyan AKMI, Sakib N, Pakpour AH, Griffiths MD, Mamun MA. COVID-19Related Suicides in Bangladesh Due to Lockdown and Economic Factors: Case Study Evidence from Media Reports. Int J Ment Health Addict. 2020: 15 :1-6. doi:10.1007/s11469-020-00307-y 